\title{
Increased extracellular polymeric substances production contributes for the robustness of aerobic granular sludge during long-term intermittent exposure to 2-fluorophenol in saline wastewater
}

\author{
Ana S. Oliveira $^{\mathrm{a}}$, Catarina L. Amorim ${ }^{\mathrm{a}, *}$, Daniela P. Mesquita ${ }^{\mathrm{b}}$, Eugénio C. Ferreira ${ }^{\mathrm{b}}$, \\ Mark van Loosdrecht ${ }^{c}$, Paula M.L. Castro ${ }^{\mathrm{a}}$ \\ ${ }^{a}$ Universidade Católica Portuguesa, CBQF - Centro de Biotecnologia e Química Fina - Laboratório Associado, Escola Superior de Biotecnologia, Rua Diogo Botelho 1327, \\ 4169-005 Porto, Portugal \\ ${ }^{\mathrm{b}}$ CEB - Centre of Biological Engineering, Universidade do Minho, Campus de Gualtar, 4710-057 Braga, Portugal

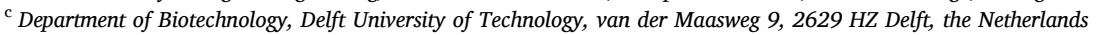

\section{A R T I C L E I N F O}

\section{Keywords:}

Aerobic granular sludge

Extracellular polymeric substances

2-Fluorophenol

Salinity

Granular morphology

\begin{abstract}
A B S T R A C T
Industrial effluents often contain organic pollutants and variable salinity levels, making their treatment challenging. The high content of extracellular polymeric substances (EPS) in the aerobic granular sludge (AGS) is thought to protect the microbial communities from stressful conditions. Ammonium and phosphate removal, EPS production, and granular morphology were assessed in a lab-scale AGS reactor operated during 138 days at continuous low or moderate salinity levels $(1.41-6.46 \mathrm{~g} / \mathrm{L}$ of $\mathrm{NaCl}$ ) and intermittent short-term loadings of a fluoroorganic pollutant, 2-fluorophenol (2-FP, $20 \mathrm{mg} / \mathrm{L}$ ). 2-FP was not degraded throughout operation. Ammonium removal efficiency was drastically affected whenever 2-FP stressor was present, decreasing from 99 $\%$ to non-detectable conversion levels, but completely recovering after 2-FP feeding ceased. Phosphate removal, initially disturbed by exposure to stress conditions, recovered with time, even when stressors were still present. Complete phosphate removal did not occur in periods when nitrite temporarily accumulated after nitrification started to recover. EPS composition and concentration in AGS varied during operation, initially decreasing from 133 to $34 \mathrm{mg} / \mathrm{g}$ vSS of AGs, during the stress phases but recovering thereafter to $176 \mathrm{mg} / \mathrm{g}_{\mathrm{VSS}}$ of AGs. Breakage of granules into smaller ones occurred at two different operational moments due to stressors presence. The presence of 2-FP and moderate salinity levels in wastewater had more immediate detrimental effects on nutrients removal than on EPS production. The AGS system capacity to recover the nutrient removal performance and EPS production, after the withdrawal of 2-FP from the inlet stream reinforced its robustness to deal with industrial wastewaters.
\end{abstract}

\section{Introduction}

Biological wastewater treatment is usually performed by conventional activated sludge systems. However, construction and operation of activated sludge systems requires large surface areas. Since wastewater treatment systems are needed in densely populated regions, land is a limited resource [1]. Aerobic granular sludge (AGS) is an innovative and compact wastewater treatment system that has been adopted in several countries. Currently, there are more than 67 Nereda ${ }^{\circledR}$ wastewater treatment plants (WWTPs) in operation, under construction or in design (https://www.royalhaskoningdhv.com/en-gb/nereda/nereda-plants).
Although mainly applied for the treatment of urban wastewater, the compactness of the technology makes it also very useful for industrial wastewater treatment.

AGS, a special case of suspended biofilm, is composed of selfimmobilized microorganisms that form spherical sludge aggregates [2]. Microorganisms are embedded in a self-produced matrix, called extracellular polymeric substances (EPS) [3]. AGS has interesting properties such as exceptional settling ability, high biosorption capacity, ability to simultaneously remove organic carbon, nitrogen and phosphorus $[4,5]$. EPS are high molecular weight polymers, that either result from microorganisms' metabolism or cell lyses. Accumulation of such

\footnotetext{
* Corresponding author.

E-mail address: camorim@porto.ucp.pt (C.L. Amorim).
} 
EPS on the cells surface forms a protective barrier for the cells against the external environment [3,6]. EPS can affect the entire AGS microbial surface and consequently the capacity of aggregation, biosorption, mass transfer and structural stability, important features for the removal of organic pollutants [7].

Wastewater biotreatment, including the AGS process, can face several difficulties when treating industrial wastewater due to the variable chemical composition; the presence of recalcitrant and toxic compounds; the presence of salts; and starvation periods due to production process fluctuations [8-10]. Industries such as the chemical, pharmaceutical, agro-food, petroleum, textile and leather industries, generate large amounts of saline wastewater, which often contain (micro)pollutants [11]. Phenolic compounds, including fluorophenols, are within the most toxic and recalcitrant compounds often present in industrial wastewaters, specifically effluents from the production of pharmaceuticals, bulk chemicals, herbicides, and pesticides [12,13]. Some studies focused on the aerobic treatment of saline wastewater polluted with organic compounds typically found in the industrial sector: Kokabian et al. [14] and Assadi et al. [15] studied the effect of salts on the performance of activated sludge systems treating azo dyes from the textile industry; Corsino et al. [16] and Campo and Di Bella [17] reported the cultivation of AGS and treatment of wastewater simultaneously containing hydrocarbons and aromatic hydrocarbons from petrochemical pollution, and high salt $(\mathrm{NaCl})$ concentration; Ramos et al. [18] and Ramos et al. [19] reported the effect of salinity on AGS treating a mixture of aromatic compounds (phenol, o-cresol, p-nitrophenol, and quinoline). Nevertheless, there are no reports on the use of AGS to treat wastewater characterized by the simultaneous presence of halogenated aromatics pollutants and salinity. Duque et al. [20] and Ramos et al. [21] evaluated the effect of 2-fluorophenol (2-FP) as the sole stressor in wastewater on AGS bioreactor performance. However, 2-FP toxic effect was in fact attenuated by bioaugmentation with a degrading strain.

EPS production is regarded as one of the protective strategies for bacteria in biofilms to survive and grow in stressful environments [3,6, 7]. However, whether secretion of EPS by AGS microbial community changes during exposure to harsh environments is not a well-researched issue. In the present study, we aimed at investigating the effect of the toxic compound 2-FP combined with low to moderate salinity (1.41-6.46 g/L of $\mathrm{NaCl}$ ) wastewater on the performance of a lab-scale AGS system and on the EPS secreted by the microbial community within the granules. In order to mimic transient states of composition typical of industrial effluents, the reactor inlet stream periodically varied in 2-FP presence and salt concentration. EPS composition and production was assessed during the applied stress conditions to further elucidate the EPS protection role towards the combination of stressors. To the best of our knowledge, this study presents for the first-time the effects of combined stressors, namely an halogenated aromatic pollutant and salinity, on the nutrient removal performance and EPS production of an AGS system, investigating the reliability of this low footprint technology to deal with intermittent conditions that characterize industrial effluents.

\section{Materials and methods}

\subsection{AGS sequencing batch reactor (SBR) set-up}

A 2.5 L SBR with $110 \mathrm{~cm}$ height and an internal diameter of $6.5 \mathrm{~cm}$ was inoculated with AGS from an urban WWTP at Frielas, Portugal. The WWTP receives domestic, pluvial and industrial (15-17\%) wastewater.

The bioreactor was operated at room temperature performing treatment cycles of $3 \mathrm{~h}$, as followed: $60 \mathrm{~min}$ of inlet anaerobic feeding (introduced at the SBR bottom), $112 \mathrm{~min}$ of aeration (bottom aeration supplied at an airflow rate of $4 \mathrm{~L} / \mathrm{min}$, superficial air velocity of $84.8 \mathrm{~m} /$ h), 3 min of settling and 5 min of effluent withdrawal. Approximately 40 $\%$ of the reactor liquid was withdrawn in each cycle. Particles with settling velocity greater than $6 \mathrm{~m} / \mathrm{h}$ were retained in the reactor, whereas particles with lower settling velocity were withdrawal. The $\mathrm{pH}$ was maintained at 7.0-8.0 by dosing $1 \mathrm{M} \mathrm{NaOH}$ or $1 \mathrm{M} \mathrm{HCl}$.

Throughout phase I, the synthetic influent media used was as described by de Kreuk et al. [22]. Briefly, synthetic influent media was composed by: $\mathrm{NaCH}_{3} \mathrm{COO} 5.17 \mathrm{~g} / \mathrm{L}, \mathrm{MgSO}_{4} .7 \mathrm{H}_{2} \mathrm{O} 0.89 \mathrm{~g} / \mathrm{L}, \mathrm{KCl} 0.35$ $\mathrm{g} / \mathrm{L}, \mathrm{NH}_{4} \mathrm{Cl} 1.89 \mathrm{~g} / \mathrm{L}, \mathrm{K}_{2} \mathrm{HPO}_{4} 0.60 \mathrm{~g} / \mathrm{L}, \mathrm{KH}_{2} \mathrm{PO}_{4} 0.29 \mathrm{~g} / \mathrm{L}$, and $10 \mathrm{~mL} / \mathrm{L}$ of trace element solution. From day-133 onwards, variable influent media composition was applied to mimic real industrial streams where recalcitrant pollutants are present intermittently $[8,10,23]$ along with low $(1.4 \mathrm{~g} / \mathrm{L} \mathrm{NaCl})$ to moderate salinity $(3.1-6.5 \mathrm{~g} / \mathrm{L} \mathrm{NaCl})$ levels, according to the classification of water based on salinity levels described elsewhere [24,25]. During saline and 2-FP transient states (phases II-X), $\mathrm{NaCl}$ and 2-FP were added to medium in order to reach a concentration in the inlet flow as indicated in Table 1 . The $\mathrm{NaCl}$ concentration chosen for this study, was within the concentration stated in the literature for chemical industry wastewater [9]. 2-FP was chosen as a model fluorinated compound present in industrial effluents, and the concentration used in the present study is similar to those present in wastewater from other studies [20].

\subsection{Analytical methods}

The granular sludge bed-volume was determined after 3 min settling using a graduated scale placed on the reactor column. Effluent total suspended solids (TSS) and volatile suspended solids (VSS) were analyzed in accordance with standard methods [26].

Samples collected from the inlet, influent and effluent bioreactor were filtered in order to remove biomass using non-sterile syringe membrane filters, $0.45 \mu \mathrm{m}$ pore size (Chromafil ${ }^{\circledR}$ PET filters, MachereyNagel, Germany). Quantification of phosphate $\left(\mathrm{PO}_{4}^{3-}-\mathrm{P}\right)$, ammonium $\left(\mathrm{NH}_{4}^{+}-\mathrm{N}\right)$, nitrite $\left(\mathrm{NO}_{2}^{-}-\mathrm{N}\right)$, and nitrate $\left(\mathrm{NO}_{3}^{-}-\mathrm{N}\right)$ was performed as described by Amorim et al. [27]. Phosphate and ammonium removal efficiency were calculated using the following equation: Removal efficiency $(\%)=\left(C_{i}-C_{f}\right) \times 100 / C_{i}$, where $C_{i}$ and $C_{f}$ are the inlet and effluent concentrations of phosphate or ammonium.

2-FP quantification was performed using a modified HPLC method described by Duque et al. [20]. Modification of the method was as followed: flow rate of $1 \mathrm{~mL} / \mathrm{min}$; mobile phase consisting of $60 \%(\mathrm{v} / \mathrm{v})$ acetonitrile and $40 \%(\mathrm{v} / \mathrm{v})$ water acidified with trifluoroacetic acid; running time of $7 \mathrm{~min}$ (elution time ca. $3.2 \mathrm{~min}$ ); compound detection at $210 \mathrm{~nm}$ using a diode array detector. Quantification of fluorine ions in the influent and effluent filtrate was performed by a potentiometric method as described by Duque et al. [20].

\subsection{Image analysis}

AGS from the lab-scale bioreactor, before and during stress conditions, was collected to assess morphology by image analysis. Granules were collected simultaneously to the ones collected for EPS extraction

Table 1

2-FP and $\mathrm{NaCl}$ concentrations at the inlet fed to the reactor throughout its operation.

\begin{tabular}{llll}
\hline \multirow{2}{*}{ Phase } & Duration (operation days) & \multicolumn{2}{l}{ Inlet concentration } \\
\cline { 3 - 4 } & & 2 -FP $(\mathrm{mg} / \mathrm{L})$ & $\mathrm{NaCl}(\mathrm{g} / \mathrm{L})$ \\
\hline I & $132(\mathrm{~d} 0-\mathrm{d} 132)$ & 0 & 0 \\
II & $6(\mathrm{~d} 133-\mathrm{d} 139)$ & 0 & 1.4 \\
III & $6(\mathrm{~d} 140-\mathrm{d} 146)$ & 20.0 & 1.4 \\
IV & $6(\mathrm{~d} 147-\mathrm{d} 153)$ & 0 & 3.1 \\
V & $6(\mathrm{~d} 154-\mathrm{d} 160)$ & 20.0 & 3.1 \\
VI & $6(\mathrm{~d} 161-\mathrm{d} 167)$ & 0 & 6.5 \\
VII & $6(\mathrm{~d} 168-\mathrm{d} 174)$ & 20.0 & 6.5 \\
VIII & $6(\mathrm{~d} 175-\mathrm{d} 181)$ & 0 & 6.5 \\
IX & $6(\mathrm{~d} 182-\mathrm{d} 188)$ & 20.0 & 6.5 \\
X & $81(\mathrm{~d} 189-\mathrm{d} 270)$ & 0 & 1.4 \\
\hline
\end{tabular}


and biochemical characterization. Four samples were collected during phase I (due to its longer duration) and one sample per phase was collected during phases II-X. After granules collection (during the aeration phase of the treatment cycle), samples were subjected to a procedure described elsewhere to preserved biomass properties until analysis [28]. Image analysis evaluated the equivalent diameter (Deq), area (\%), number (\%), and roundness of granules as described elsewhere $[21,29,30]$.

\subsection{Extraction and characterization of EPS from granules}

EPS extraction was done using sodium carbonate $\left(\mathrm{Na}_{2} \mathrm{CO}_{3}\right)$, heat $\left(80^{\circ} \mathrm{C}\right)$ and magnetic stirring. This extraction procedure rendered a higher yield than other commonly used procedures tested by Felz et al. [31]. Four consecutive extractions were performed using the pellet obtained in each previous extraction to increase the extraction yield. Subsequently, an acidic precipitation step was performed to extract structural EPS [31] and potentiate the EPS compositional homogeneity [28]. EPS biochemical characterization was made using colorimetric methods to access the proteins [32], polysaccharides [33] and humic acids like contents [34].

\subsection{Statistical analysis}

Statistical analysis was performed using the SPSS program (SPSS Inc., Chicago, IL Version 26.0). Each EPS extraction comprised six replicates $(n=6)$. Normal distribution was verified with the Shapiro-Wilk test, $\mathrm{p}>0.05$ was considered significant. The statistical analysis was carried out by one-way ANOVA and subsequent post-hoc Tukey comparison, with $\mathrm{p}<0.05$ established for significance, to investigate differences in the concentration of each EPS component.

\section{Results and discussion}

\subsection{AGS-SBR performance}

\subsubsection{2-FP fate in the bioreactor}

During phases I and II there was no addition of 2-FP to the inlet feeding, while salinity increased during phase II. From phase III to IX the reactor was exposed to intermittent loadings of 2-FP at a stepwise increase of salt concentration. 2-FP was continuously fed at $20.0 \mathrm{mg} / \mathrm{L}$ for six consecutive days followed by a period of six days without 2-FP feeding (Table 1). Fig. 1 shows the profile of 2-FP concentration in the bioreactor. 2-FP was not degraded during bioreactor operation which was also confirmed by the absence of fluorine release. Additionally, metabolite formation was also not observed (data not shown). There was no acclimatization of the biomass to the toxic compound, as also observed in previous studies with the same compound [20,35]. Thus, removal of the toxic compound may have occurred due to adsorption of 2-FP onto granules, similar to what was observed in a previous study [35]. In the first cycle of each 2-FP feeding phases, the concentration of 2-FP after the anaerobic feeding was found to be lower than expected based on the feeding concentration and the dilution inside the reactor. Biomass adsorbed about $7.19 \mathrm{mg}, 5.77 \mathrm{mg}, 5.01 \mathrm{mg}$, and $2.93 \mathrm{mg}$ of 2-FP in phases III, V, VII, and IX, respectively, with its sorption capacity decreasing from 95 to $39 \%$. This consistent decrease of 2-FP adsorption onto granules at the beginning of successive phases may have been due to the stepwise salinity increase. In fact, $\mathrm{NaCl}$ may have competed with 2-FP for adsorption binding sites, as reported by other studies [36-38]. Noteworthy, the amount of biomass inside the reactor during those phases was similar (bed volume, Section 3.2), which does not explain the variations in the amount of 2-FP adsorbed to the biomass. During phases III (feeding with $20.0 \mathrm{mg} / \mathrm{L}$ of 2-FP and $1.4 \mathrm{~g} / \mathrm{L}$ of $\mathrm{NaCl}$ ) and $\mathrm{V}$ (feeding with $20.0 \mathrm{mg} / \mathrm{L}$ of 2 -FP and $3.1 \mathrm{~g} / \mathrm{L}$ of $\mathrm{NaCl}$ ), 2-FP concentration in the effluent was found to be lower (ca. 13 and $53 \%$, respectively) than that expected based on 2-FP concentration detected in the influent after anaerobic feeding, indicating that the toxic compound was further adsorbed during the aerobic period of the treatment cycle. In phases VII and IX (feeding with $20.0 \mathrm{mg} / \mathrm{L}$ of 2 -FP and $6.5 \mathrm{~g} / \mathrm{L}$ of $\mathrm{NaCl}$ ), adsorption of 2-FP to granules during the aerobic period was less pronounced, with nearly all the 2-FP present in the influent after anaerobic feeding being recovered at the outlet during the respective cycles. Microbial cells and EPS in biofilms, including AGS, are key components responsible for sorption phenomena. EPS constitutes a large fraction of the AGS composition [39], especially of the outermost layer of AGS biofilms, thus sorption of 2-FP onto granules was likely to occur. The EPS are mainly composed of proteins and polysaccharides, which contributed for the existence of different functional groups (e.g., carboxyl, hydroxyl, and amine moieties) at granules surface that represent sorption sites for the organic pollutants $[4,40]$.

On the other hand, desorption of 2-FP occurred in the first cycle of phases after stopping 2-FP feeding (IV, VI, VIII, and X), as the concentration of 2-FP inside the reactor was found to be higher than expected based on effluent concentration from the previous cycle (fed with 2-FP) and the dilution in the reactor. Desorption of 5.48, 2.05, 3.54, and 0.96 $\mathrm{mg}$ of 2-FP in the first cycle of phases IV, VI, VIII, and X, respectively, was observed. In those phases, 2-FP was detected in the first operation cycle in the influent after anaerobic feeding and in the effluent but not

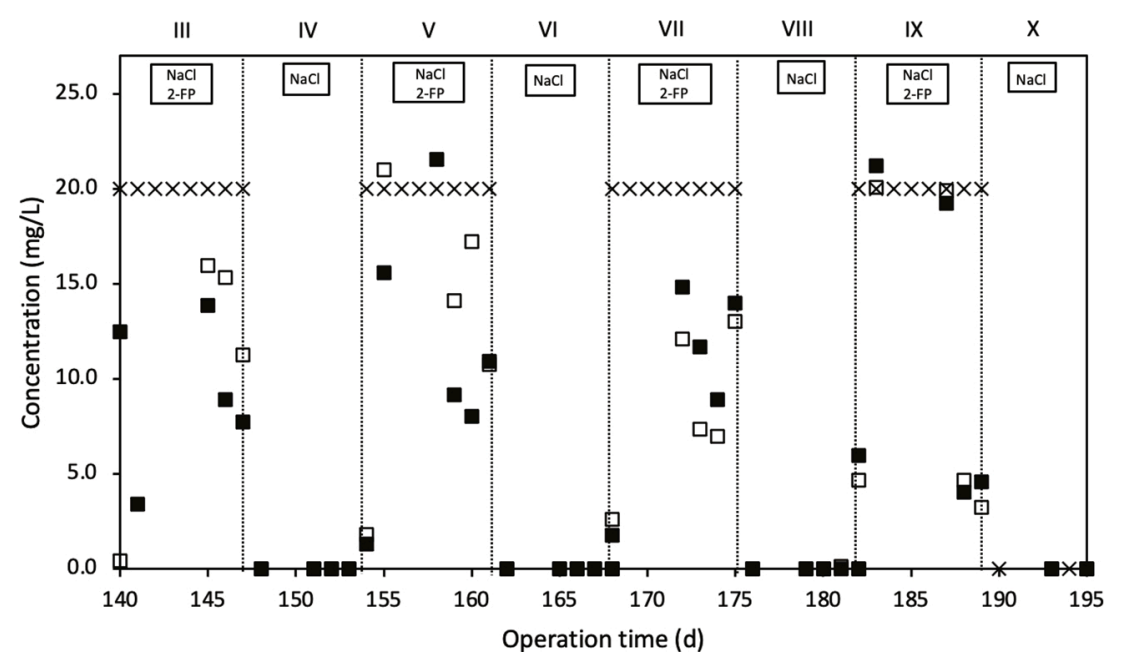

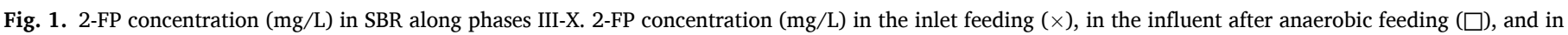
the effluent (ם). 
on the subsequent days.

\subsubsection{Phosphate and ammonium removal}

The concentrations of phosphate and nitrogen during the experimental period are shown in Fig. 2. In the absence of salt and 2-FP in the feed (phase I), phosphate removal efficiency varied between $56 \%$ and $97 \%$ (Fig. 2 a). During phases II-VI, an increase in the phosphate release during the anaerobic feeding, and a decrease in phosphate removal during the aerobic period were observed, probably as a result of the shock loads of 2-FP and salinity. However, by the end of each of those phases there was an increase in the phosphorous removal efficiency, which is an indication that the system was quickly adapting and starting to recover the ability to remove phosphate. During phases VII-IX (feeding with $6.5 \mathrm{~g} / \mathrm{L}$ of $\mathrm{NaCl}$ and intermittent presence of $20.0 \mathrm{mg} / \mathrm{L}$ of 2-FP), the phosphate release during the anaerobic feeding and phosphate removal efficiency stabilized (94-97\%), indicating that the 2-FP shock loads and salinity were no longer affecting the system's ability to remove phosphate as previously. Throughout phase $\mathrm{X}$ (feeding with $1.4 \mathrm{~g} / \mathrm{L}$ of $\mathrm{NaCl}$ ), phosphate removal efficiency increased from 6 to $70 \%$, but did not achieve full removal during the experimental period.

The concentration of ammonium in the bioreactor effluent during phase I was very low, indicating high ammonium removal efficiency, around $98-100 \%$ (Fig. 2 b). In phase II, the introduction of salt in the feeding $(1.4 \mathrm{~g} / \mathrm{L})$ did not affect the ammonium removal efficiency, which remained at $100 \%$. During phase III (feeding with $20.0 \mathrm{mg} / \mathrm{L}$ of 2 $\mathrm{FP}$ and $1.4 \mathrm{~g} / \mathrm{L}$ of $\mathrm{NaCl}$ ), a decrease in the ammonium removal efficiency was observed, probably due to the first shock load of 2-FP. From phase IV to phase IX, during which $\mathrm{NaCl}$ in the feeding medium increased from 3.1 to $6.5 \mathrm{~g} / \mathrm{L}$ and 2-FP was present intermittently, the ammonium removal efficiency was extremely low, reaching $0 \%$. However, when 2 - (a)

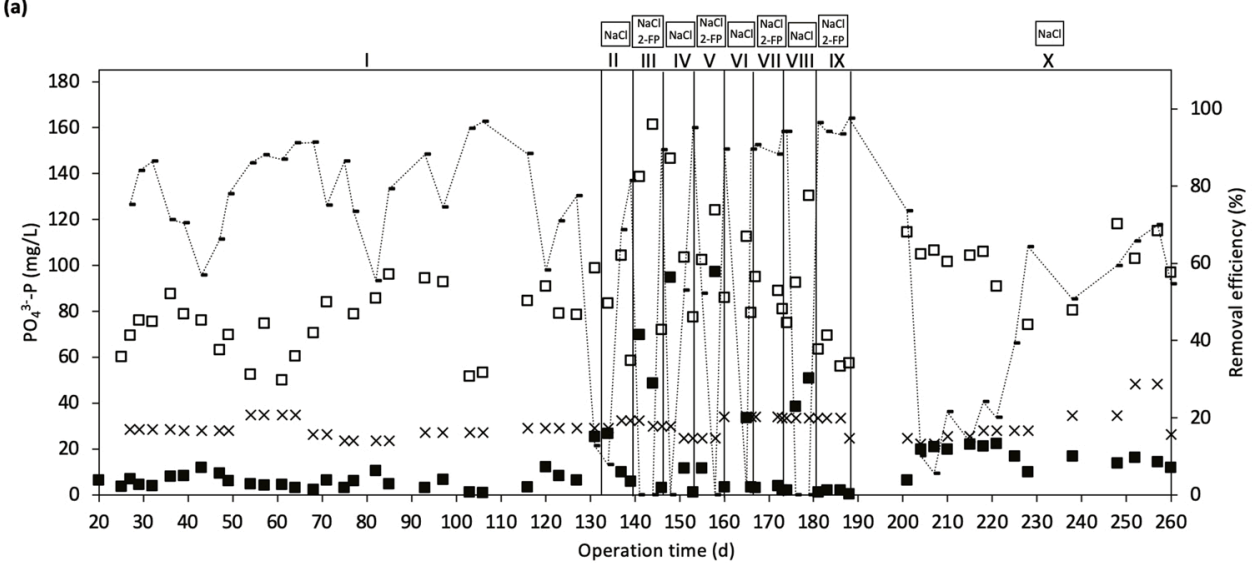

Fig. 2. $\mathrm{PO}_{4}^{3-}-\mathrm{P}(\mathrm{a}), \mathrm{NH}_{4}^{+}-\mathrm{N}(\mathrm{b})$, and $\mathrm{NO}_{2}^{-}-\mathrm{N}$ and $\mathrm{NO}_{3}^{-}-\mathrm{N}$ (c) concentration profile along operation. Concentration $\left(\mathrm{mg} \mathrm{L}^{-1}\right)$ of $\mathrm{PO}_{4}^{3-}$ in the inlet feeding $(\times), \mathrm{PO}_{4}^{3-}$ in the influent after anaerobic feeding $(\square), \mathrm{PO}_{4}^{3-}$ in the effluent $(\square)$, $\mathrm{NH}_{4}^{+}$in the inlet feeding $(+), \mathrm{NH}_{4}^{+}$in the influent after anaerobic feeding $(\diamond), \mathrm{NH}_{4}^{+}$in the effluent $(\diamond), \mathrm{NO}_{2}^{-}$in the influent after anaerobic feeding $(\triangle), \mathrm{NO}_{2}^{-}$in the effluent $(\mathbf{\Lambda}), \mathrm{NO}_{3}^{-}$ in the influent after anaerobic feeding (o), $\mathrm{NO}_{3}^{-}$ in the effluent (๑). $\mathrm{PO}_{4}^{3-}$ and $\mathrm{NH}_{4}^{+}$removal efficiencies (\%) are presented in the corresponding graphics (dashed and dotted line).
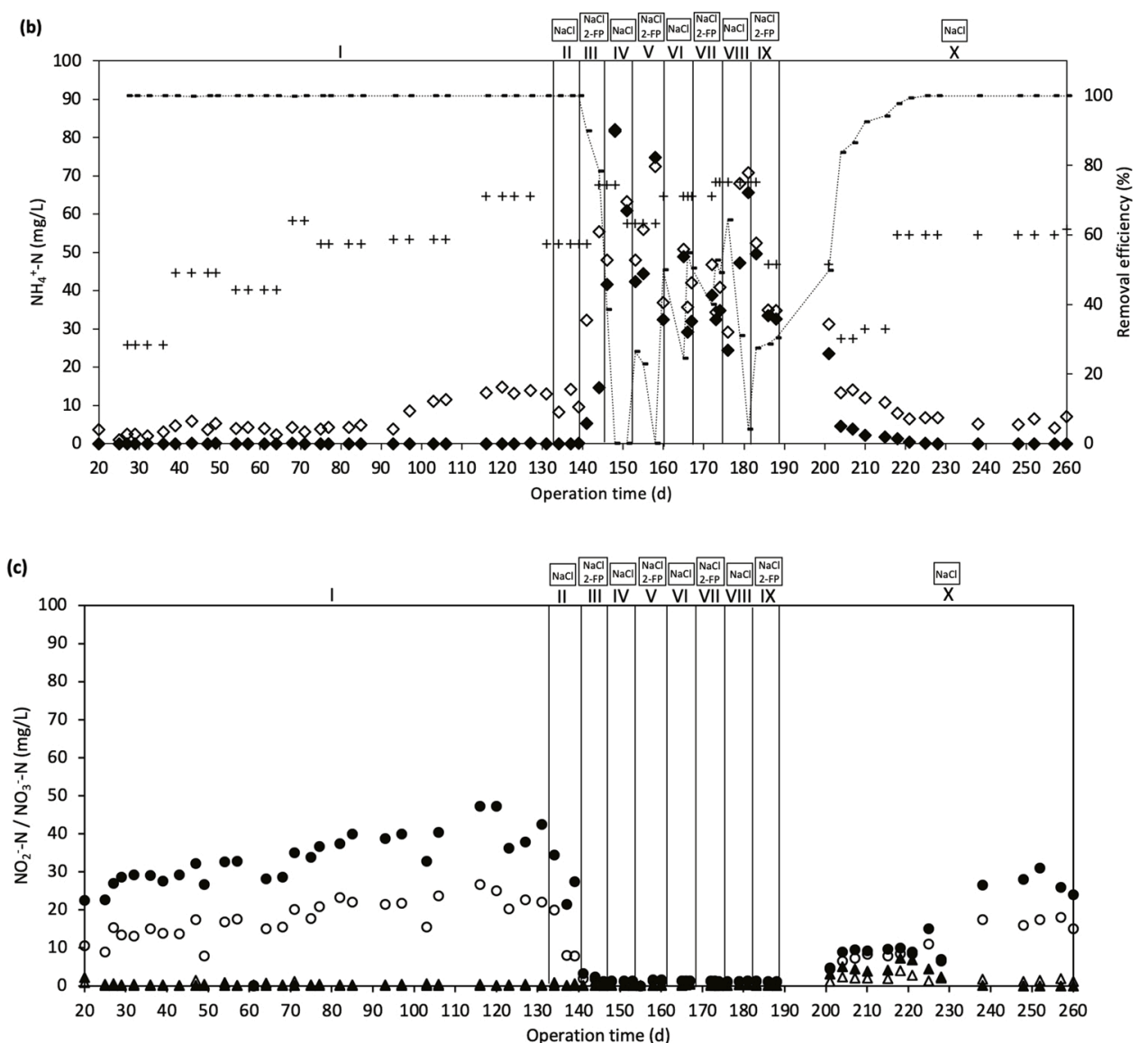
FP was eliminated from the feeding (phase $\mathrm{X}$ ), the nitrification process was completely reestablished.

The main product of nitrification during phase I was nitrate, and its concentration in the effluent reached $47 \mathrm{mg} / \mathrm{L} \mathrm{NO}_{3}^{-}-\mathrm{N}$, indicating that complete nitrification occurred. During phases III-IX (when 2-FP was intermittently introduced in the inlet feeding), low concentrations of nitrite and nitrate were observed $\left(0.1-0.4 \mathrm{mg} / \mathrm{L} \mathrm{NO}_{2}^{-}-\mathrm{N}\right.$ and $1.1-3.2 \mathrm{mg} /$ $\mathrm{L} \mathrm{NO}_{3}^{-}-\mathrm{N}$ ). After stopping 2-FP feeding, an increase in nitrite content was observed, reaching $7.4 \mathrm{mg} / \mathrm{L} \mathrm{NO}_{2}^{-}-\mathrm{N}$ (Fig. $2 \mathrm{c}$ ), due to the recovery of the ammonium oxidizing bacteria (AOB) activity in the granules and by the end of phase $\mathrm{X}$ complete nitrification was achieved, indicating a recovery of the nitrite oxidizing bacteria (NOB).

Several studies demonstrated that $\mathrm{NaCl}$ critically impairs the phosphate removal efficiency of AGS [41-43]. Interestingly, de Graaff et al. [44] observed an effective enhanced biological phosphate removal (EBPR) process performance by AGS fed with synthetic seawater, while other research has shown a negative effect on operation of AGS processes with $\mathrm{NaCl}$-based wastewater at the same salinity as seawater. Pronk et al. [37] performed a study that showed that an increase of up to $6.6 \mathrm{~g} / \mathrm{L} \mathrm{Cl}^{-}$in the inlet feeding of an AGS-SBR system, led to a decrease of phosphate uptake rates in the first days, recovering after a few days. Further increase of the salt content in the inlet feeding caused phosphate uptake rates to decline. Similarly, in the present study, phosphate uptake was affected by the gradual increase in salinity, which would then recover days later. However, phosphate uptake was not completely reestablished in phase $\mathrm{X}$, when $\mathrm{NaCl}$ in the inlet feeding decreased to 1.4 $\mathrm{g} / \mathrm{L}$. This observation is intrinsically connected to the nitrification process in the reactor. The recovery of activity of AOB in phase $\mathrm{X}$ was not accompanied by the NOB, leading to the accumulation of nitrite. Saito et al. [45], have reported the detrimental effect of nitrite on phosphate removal efficiency. Nitrite at $2 \mathrm{mg} / \mathrm{L} \mathrm{NO}_{2}^{-}-\mathrm{N}$ caused a severe decrease on polyphosphate-accumulating organisms (PAO) activity and a complete inhibition of the aerobic phosphate uptake occurred above $6 \mathrm{mg} / \mathrm{L}$ $\mathrm{NO}_{2}^{-}$-N. In the present study, when nitrite accumulation decreased, around day-235, the phosphate removal efficiency started to increase, reaching $70 \%$ by the end of the experimental period. The long exposure to nitrite (24 days) could have had a detrimental effect on PAOs, leading to a reduction of this microbial population, which takes time to be recovered, as reported by previous studies [46].

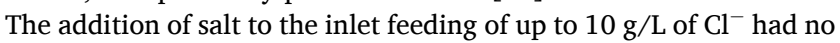
negative effect on the ammonium removal efficiency, as seen in previous studies $[42,43,47]$. Nevertheless, ammonium removal was significantly impaired by the presence of halogenated phenolic pollutants. Wei et al. [48] reported that the feeding of $10 \mathrm{mg} / \mathrm{L}$ of an halogenated phenol, 4-chlorophenol, to an AGS-SBR system led to a decrease of ca. $59 \%$ in ammonium removal efficiency. Lim et al. [49] and Jemaat et al. [23] described a strong inhibitory effect of 2,4-dichlorophenol and 2-chlorophenol, respectively, on ammonium removal of AGS bioreactors. In another study Ramos et al. [21] performed the bioaugmentation of an AGS-SBR system with a 2-FP specialized degrading strain, achieving partial nitrification and complete 2-FP degradation. In the present study, without bioaugmentation no 2-FP removal occurred, leading to the inhibition of the nitrification. Additionally, AOB seemed to be more affected by 2-FP than PAO, as the phosphate removal recovered even during periods with 2-FP presence. The layered structure of granules might cause this finding, as AOB (and NOB) are mainly in the outer layer (aerobic zone) of granules and, consequently, more exposed to toxics, than PAO that are in the inner layers $[1,10,50]$.

\subsection{AGS settling properties and morphology features}

The bed volume of the AGS and solid content of the effluent of the bioreactor were regularly measured during the operation (Fig. 3). When stress conditions started, in phase II (feeding with $1.4 \mathrm{~g} / \mathrm{L}$ of $\mathrm{NaCl}$ ), the bed volume was maintained, and the solid content in the effluent showed low values indicating that the level of salinity applied did not

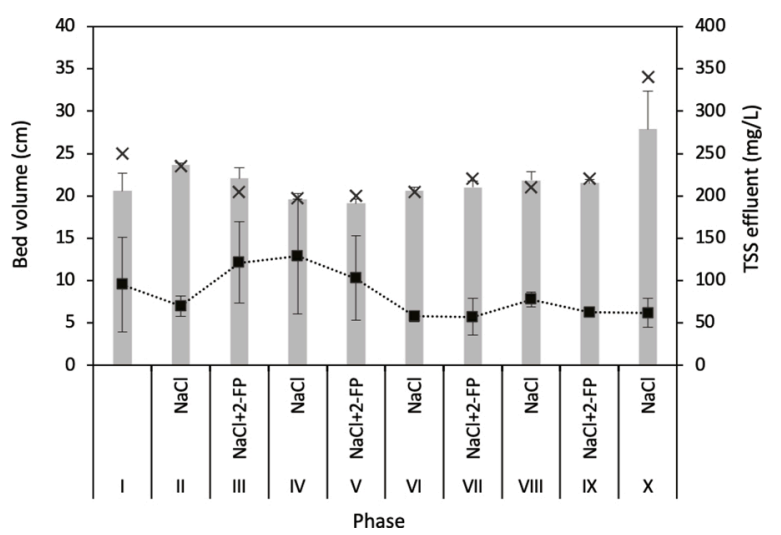

Fig. 3. Bed volume and effluent TSS profile during SBR operation. Columns represent the average bed volume of each phase, data points represent the bed volume on the last day of each phase $(\times)$, and average TSS in the effluent $(\boldsymbol{\square})$. Error bars represent the standard deviation.

cause a considerable detrimental effect on the AGS-SBR. Subsequently, after 2-FP feeding started, the bed volume started to decrease gradually, reaching its minimum values in phases IV (feeding with $3.1 \mathrm{~g} / \mathrm{L}$ of $\mathrm{NaCl}$ ) and $\mathrm{V}(20.0 \mathrm{mg} / \mathrm{L}$ of $2-\mathrm{FP}$ and $3.1 \mathrm{~g} / \mathrm{L}$ of $\mathrm{NaCl})$, accompanied by an increase of the solid content in the effluent in those phases. Therefore, during phases IV and V, it is likely that granules were starting to disintegrate and break into smaller fragments, due to the presence of 2-FP and a higher salinity at the inlet medium. Nevertheless, in subsequent phases VI-IX, a slight increase of bed volume and a decrease of TSS were observed showing that after the initial disturbance observed due to the introduction of 2-FP in the feeding, the biomass was able to cope with the increase in salinity and with the intermittent load of 2-FP. In phase X (feeding with $1.4 \mathrm{~g} / \mathrm{L}$ of $\mathrm{NaCl}$ ), after stopping 2-FP feeding, the bed volume increased, reaching its maximum value, and solids content in the effluent maintained low. Previous studies showed that feeding of AGS reactors with fluorinated compounds, such as fluoroquinolones (antibiotics) and fluoxetine (antidepressant) can lead to similar effects on AGS properties, decreasing sludge bed volume and increasing effluent solid content, which recovered and stabilized after ceasing the feeding with such compounds [51,52].

The morphological characteristics (Deq, area (\%), number (\%), and roundness) of the granular biomass during the operational period are shown in Fig. 4 (a, b, c, and d, respectively). The granules were classified according to their equivalent diameter into: small granules (Deq $<150$ $\mu \mathrm{m})$, intermediate granules $(150 \leq$ Deq $<1500 \mu \mathrm{m})$, and large granules (Deq $\geq 1500 \mu \mathrm{m}$ ). Minor variations of small and large granules Deq values were observed, while intermediate granules Deq values suffered significant variations. With respect to granules' area (\%) and number (\%), a generalized increase of intermediate granules and a decrease of large granules occurred throughout operation, which indicated that large granules could have broken into intermediate size granules. Exceptionally, during phases IV (feeding with $3.1 \mathrm{~g} / \mathrm{L}$ of $\mathrm{NaCl}$ ) and $\mathrm{X}$ (feeding with $1.4 \mathrm{~g} / \mathrm{L}$ of $\mathrm{NaCl}$ ), a significant decrease of the number (\%) of intermediate granules was observed, from 76 to $65 \%$ and from 91 to $70 \%$, ultimately leading to an increase of small granules number (\%) from 18 to $33 \%$ and from 6 to $29 \%$, respectively. Likely, breakage of intermediate granules into smaller ones occurred due to the stress conditions applied. Results from bed volume and effluent solids content (Fig. 3) suggest that in phase IV, the granules' breakage process resulted not only in smaller granules but also in washed-out solid content debris. Granules' breakage process and the observed increase of effluent solids content may likely be associated with the release of dispersed bacteria to the bulk, possibly leading to the loss of slow-growing nitrifying bacteria, that grow at the granules outer layer, as reported by Bassin et al. [53]. Results in Section 3.1.2 corroborate this hypothesis, as the lowest ammonium removal efficiencies occurred in phase IV. 

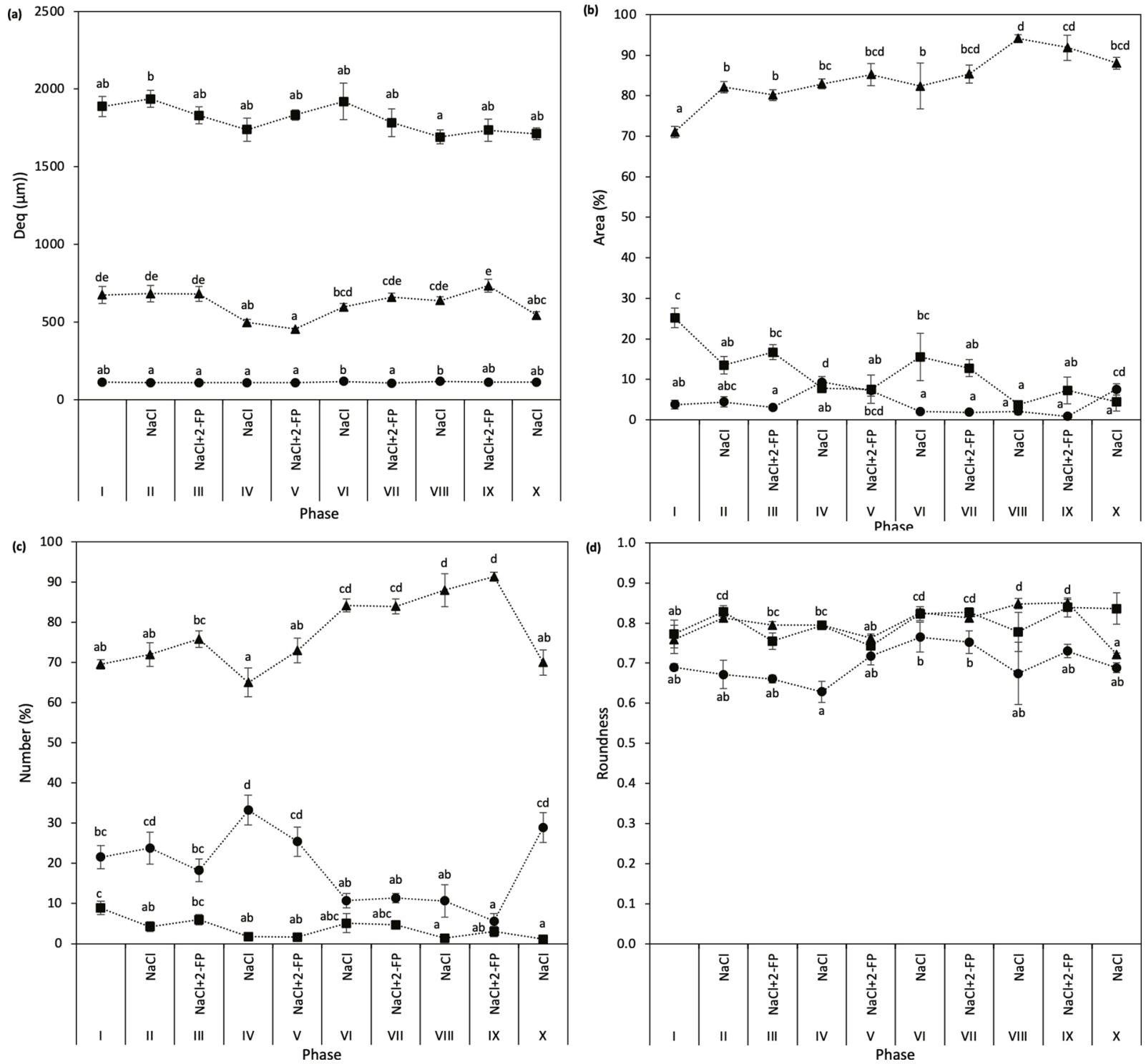

Fig. 4. The biomass was divided into three granule size classes according to its Deq: small granules ( $\bullet$ ), intermediate ( $\mathbf{\Delta})$, and large ( $\boldsymbol{\square})$. Deq (a), area (\%) of granules of each size (b), number (\%) of granules of each size (c), and roundness of each size (d). Phase I data points represent the average of the last sample of this phase. Three samples $(n=3)$ of granules were used for image analysis. Marks and error bars represent average and standard deviation of the evaluated parameters. Means that do not share a letter in the mark of the same group differed significantly according to Tukey's test at $\mathrm{p}<0.05$; roundness of large granules did not differ significantly, and therefore, the letters on that graph correspond only to small and intermediate granules.

On the other hand, in phase $\mathrm{X}$, the obtained small granules remained in the bioreactor contributing to the bed volume increase (Fig. 3). Previous studies indicate that intermediate and small granules are often originated from the breakage of large granules as the originated fragments will act as a viable seed material for subsequent re-growth of fragments [21,28]. In fact, such changes in the granules' diameter were accompanied by an increase on the efficiency of the nitrification processes which is probably related with changes in the oxygen concentration gradient within the granules, as reported in previous studies [54, 55]. Furthermore, contrarily to that observed in phase IV, in phase $X$, the ammonium removal process completely recovered (Section 3.1.2.), indicating that the granules' breakage process and subsequent loss of functional biomass was less pronounced. Nevertheless, in phase X the bioreactor community was exposed to a lower salinity for a longer period ( $1.4 \mathrm{~g} / \mathrm{L}$ of $\mathrm{NaCl}$ for 81 days) than in phase IV $(3.1 \mathrm{~g} / \mathrm{L}$ of $\mathrm{NaCl}$ for 6 days), which may have contributed for the system's nitrification recovery.

Amorim et al. [27] had also reported an increase of the number (\%) of intermediate granules $(500 \leq$ Deq $<1000 \mu \mathrm{m})$ during the feeding of an AGS-SBR system with a mixture of chiral pharmaceuticals. A previous study by Oliveira et al. [28], which evaluated the morphological characteristics of AGS biomass from a full-scale Nereda ${ }^{\circledR}$ reactor in Frielas, Portugal, revealed that small granules predominated in number (\%) in the bioreactor, but large granules had the higher area (\%). However, full-scale and lab-scale AGS systems are subject to different conditions, which could be the basis for the observed contrasting results regarding granules size predominance. A study by Mesquita et al. [56] indicated that results obtained with synthetic wastewater cannot be directly extrapolated to real wastewater.

The granules roundness, a morphology feature indicative of granular stability, differ significantly throughout operation for the small and intermediate granules, whereas large granules showed consistent roundness (Fig. 4 d). Images of granules depicting the three defined size classes from day-33 (at the beginning of phase I, where no stress conditions were applied), day-188 (phase IX, the last phase of 2-FP feeding), and day-270 (phase $\mathrm{X}$, at the end of bioreactor operation) are shown in 


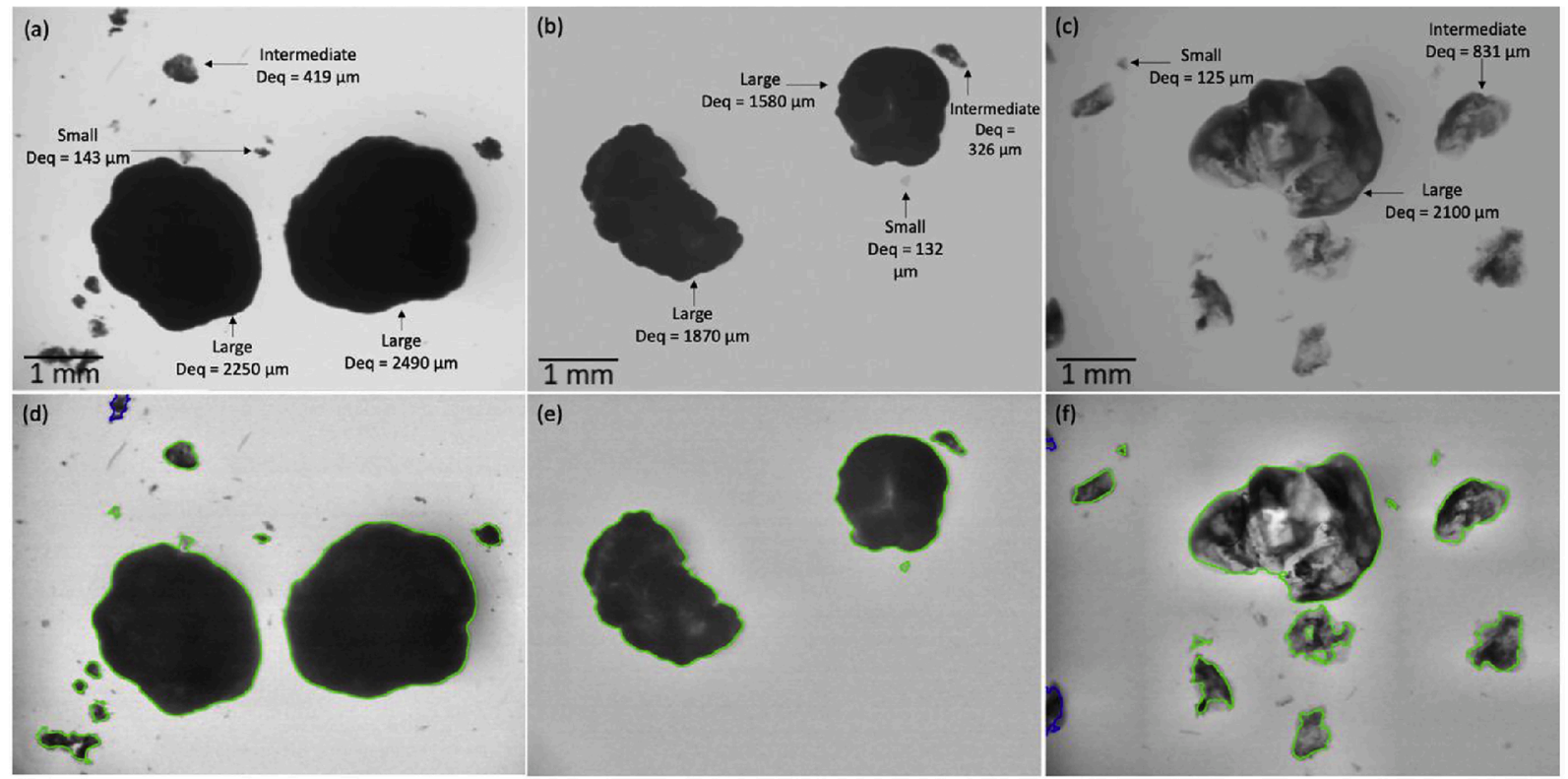

Fig. 5. Image acquisition of granules from (a) operation day-33 (phase I), (b) day-188 (phase IX), (c) day-270 (end of bioreactor operation, phase X). Granules Deq are indicated in each image. Granules as they are recognized by the software from (d) day-33, (e) day-188 and (f) day-270 are also shown.

Fig. 5. At the end of bioreactor operation granules appear to be more irregularly shaped and less spherical than at the start of operation. The applied stress conditions could be the basis for the observed appearance modification. In phase $\mathrm{X}$, after stopping 2-FP feeding, the bed volume increased, reaching its maximum value, while the solids content in the effluent remained low (Fig. 3). Nonetheless, the bed volume increase in phase $\mathrm{X}$ could be due to a biomass production increase, but also due to the increase of interstitial spaces between irregularly shaped granules.

Overall, image analysis allowed to observe that during the operation of the reactor the biomass remained relatively stable, although in two periods (phases IV and $\mathrm{X}$ ) slight granules breakage phenomena was observed due to the stressors feeding. However, AGS has proven to be a dynamic system, able to cope with the introduced stress conditions reestablishing the nutrient removal performance as shown in Section 3.1.2.

\subsection{EPS characterization}

EPS was extracted from the granules sampled in different phases. Total EPS concentration was considered to be the sum of proteins, polysaccharides and humic acids. Fig. 6 shows the concentration of each EPS component (mg/g vsS of AGS) and the protein-polysaccharide ratio (PN/PS)

Total EPS concentration recovered from AGS differed significantly between samples, ranging from $33.7 \pm 8.8$ to $176.1 \pm 19.6 \mathrm{mg} / \mathrm{g}$ vss of AGS, obtained in phase VII day-174 and phase X day-270, respectively. Proteins were the main component in all EPS samples, followed by humic acids and polysaccharides. PN/PS ratios varied between $6.3 \pm 1.2$ and $17.5 \pm 6.7$, observed in phase VI (day-165) and phase VIII (day181), respectively. The introduction of stress conditions, from phase II to VI, was characterized by a decrease on both proteins and polysaccharides content. However, proteins decrease was less pronounced than polysaccharides, rendering a higher PN/PS ratio. Sheng et al. [57] and Li et al. [58] also observed a PN/PS ratio increase in the presence of halogenated phenols, due to the increase of protein concentration. Granules sustain their structure at a high PN/PS ratio. The high PN/PS ratio range indicates that the stress conditions affected granular structure and stability, as seen in previous studies $[59,60]$.

During phase I, EPS concentration had small variations and only humic acids showed significant differences between sample from day-33 and day-124 ( $\mathrm{p}<0.05$ ); polysaccharides, proteins and total EPS concentration showed no significant differences during this phase. From phase II (feeding with $1.4 \mathrm{~g} / \mathrm{L}$ of $\mathrm{NaCl}$ ) to phase VII (feeding with $6.5 \mathrm{~g} / \mathrm{L}$ of $\mathrm{NaCl}$ and $20.0 \mathrm{mg} / \mathrm{L}$ of 2-FP in intermittent load), a generalized decrease of EPS concentration was observed, as well as of the concentration of each EPS individual component. The intermittent presence of 2-FP in the feeding complemented with the increasing salinity affected the EPS production, leading to a minimum EPS concentration observed

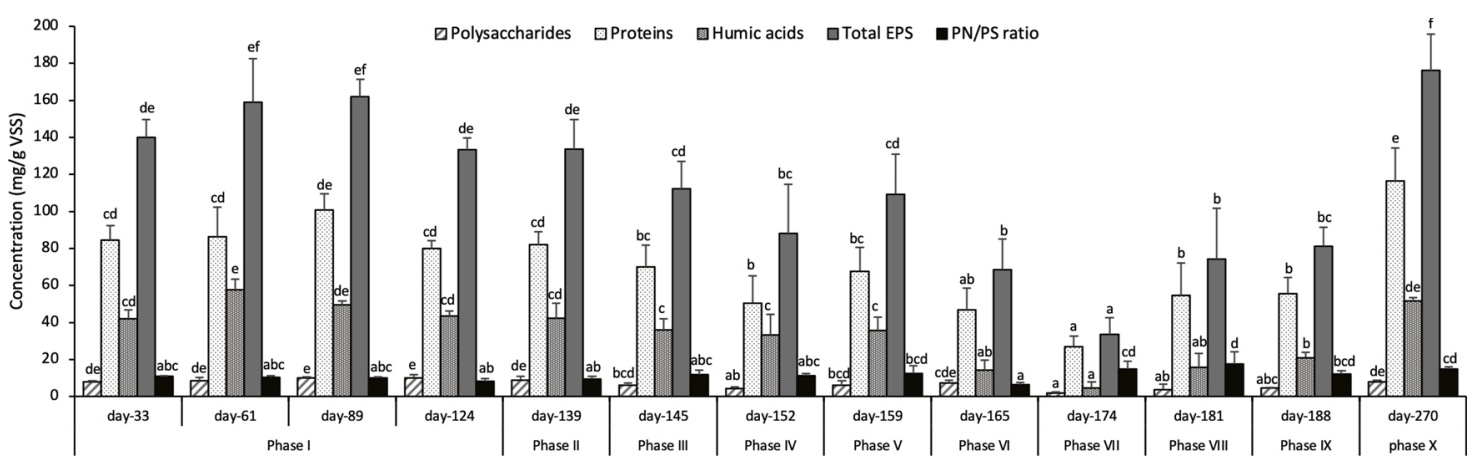

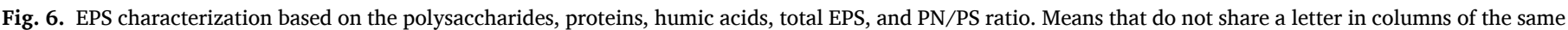
group differed significantly according to Tukey's test at $\mathrm{p}<0.05$ 
in phase VII. On subsequent phases VIII and IX, in which the salinity concentration was maintained, and 2-FP was present intermittently, an increase of EPS concentration was observed, showing that the AGS system was able to deal with the toxic and salt stresses through the production of EPS. At the end of phase X (feeding with $1.4 \mathrm{~g} / \mathrm{L}$ of $\mathrm{NaCl}$ ), EPS characterization revealed that all EPS components increased, with proteins and total EPS exhibiting their maximum concentration values during reactor operation.

EPS accumulates on the cells surface forming a protective barrier against the external environment [3,6], shielding bacteria inside the granules from toxicity, and contributing for the treatment processes resilience [61,62]. Furthermore, EPS contributes for the capacity of aggregation, mass transfer, structural stability, biosorption and biodegradation of AGS [7]. Nonetheless, when EPS concentration in the aerobic granules was higher, phase I and $\mathrm{X}$, bioreactor performance was also at its highest efficiency, indicating once again the protective function of EPS. Sheng et al. [57] and Li et al. [58], demonstrated that EPS production increased in the presence of toxics, however, toxics were introduced in the influent media as the only stress condition. Figueroa et al. [47] reported that granule formation was hampered when treating saline wastewater from a fish canning industry $\left(9 \mathrm{~g} / \mathrm{L} \mathrm{Cl}^{-}\right)$, which was related to the lack of EPS production by the biomass. Contrarily, Pronk et al. [37] did not observe a detrimental effect on granule formation nor on effluent quality at the same chloride ion concentration $\left(9 \mathrm{~g} / \mathrm{L} \mathrm{Cl}^{-}\right)$. Interestingly, in the present study, EPS production decreased successively in the early influent transient states of 2-FP and $\mathrm{NaCl}$ (phases III-VII), even though, salinity levels used were lower than the ones in the study by Figueroa et al. [47] and Pronk et al. [37]. 2-FP and $\mathrm{NaCl}$ could have had a synergistic effect in the decrease of EPS production. At the lowest EPS concentration, detected in phase VII, a possible EPS threshold was achieved, triggering the production of EPS by bacteria, as an adaptation strategy, contributing for the maintenance of the granular strength, avoiding the total disintegration of the granules, stimulating the self-aggregation ability during stress conditions, and ultimately protecting functional bacteria responsible for nutrient removal. Hence, in later transient states (phases VIII-X), in what appears to be a phase of adaptation and recovery of EPS-producing bacteria, EPS concentration started to increase. The increased EPS production in response to toxic stress in the influent, could be a late response, rather than immediate, and be preceded by a concentration decrease, as seen in this study. The observed recovery of EPS production could have contributed to bioreactor performance maintenance, thus, protecting AOB, NOB and PAO communities, to some extent, from toxic feeding. Moreover, the increased production of EPS likely allowed that granules exhibited higher sorption capacity for the toxic substances, trapping them and avoiding their penetration into the cells. Indeed, several process parameters can have an effect on the granule structure and stability, and therefore, an effect on effluent quality as shown by Wilén et al. [50]. Results in Sections 3.1.2 showed that phase III-IV and IV-V have the lowest phosphate and ammonium removal efficiencies, respectively, however, the lowest EPS concentration was observed in phase VII. This indicates that influent stress conditions have more immediate impact on the phosphate and ammonium removal efficiencies, affecting PAO and $\mathrm{AOB}$, than on EPS production activity, which seemed to be more resilient.

Interestingly, at the lowest EPS concentration in the AGS biomass (phase VII), no significant granules' breakage or desintegration process were observed. However, in phase X, when EPS concentration reached its maximum value, intermediate size granules broke into smaller ones (Section 3.2). In fact, Corsino et al. [63] reported that excess of EPS production is responsible for the clogging of granules porosity, leading to their breakage; whereas prolonged famine periods are characterized by EPS consumption by bacteria and, consequently, limited clogging of granules porosity.

Salinity can potentially disrupt biofilm composition and the EPS structure. Hence, granules size and biomass yield was shown to decrease in some studies $[38,39]$. Additionally, the presence of salts in complex matrices, such as industrial wastewaters, can intensify the inhibitory effect of organic pollutants [36]. Studies regarding the effect of salt and toxic pollutants on the simultaneous biological nutrient removal and EPS production are difficult to compare and often show different results. The reason for the distinct results obtained can be explained by the different experimental conditions, namely, $\mathrm{pH}$, temperature, the salt and toxic compounds concentrations, the way the salts and toxics are introduced in the system (as a pulse or gradual increase), the bacterial species present in the reactor (adapted or non-adapted), the organic pollutant introduced itself, and also the EPS extraction technique used.

Studies correlating EPS production and bioreactor performance in the presence of simulated industrial wastewater that introduces pollutants intermittently, in addition to salinity, are not reported to the best of our knowledge. In the present study the use of influent transient states introduces influent compositional changes ( 6 days duration) that could prevent the microbial community to adapt in terms of EPS production and simultaneous biological nutrient removal. In addition, the presence of the toxic compound indeed caused performance and EPS production disturbances, which were later recovered, emphasizing the robustness of AGS systems in dealing with intermittent presence of toxics in saline wastewater. This study thus highlights the importance of EPS producing microorganisms to avoid the deterioration of nitrification and phosphate removal processes, through the protection of key microorganisms, leading to an improvement of effluent quality.

\section{Conclusions}

An AGS-SBR was operated under different regimes of 2-FP and $\mathrm{NaCl}$ feeding, simulating the variability in industrial wastewater. As main conclusions:

- Indigenous AGS population did not degrade 2-FP.

- Ammonium removal was inhibited during 2-FP feeding but was completely reestablished upon ceasing its supply.

- Phosphate removal quickly adapted to stressors load. When ceasing 2-FP supply, nitrite accumulation inhibited PAO's activity, reestablished when nitrite levels decreased.

- EPS concentration decreased upon the initial exposure to stressors, but granule's EPS content increased later even in the presence of stress conditions. Although EPS production response was not immediate, it was efficient in maintaining the system performance.

- AGS is a robust wastewater system able to adapt to the stepwise salinity increase and the intermittent presence of 2-FP, increasing the EPS production and restoring the nutrient removal efficiency after the withdrawal of 2-FP from the inlet stream.

\section{Declaration of Competing Interest}

The authors report no conflicts of interest.

\section{Acknowledgments}

The authors wish to thank the company Águas do Tejo Atlântico, S.A. for supplying the granules. This work was financed by Fundação para a Ciência e Tecnologia (FCT, Portugal) under the project AGeNT - PTDC/ BTA-BTA/31264/2017 (POCI-01-0145-FEDER-031264). We would like to thank the scientific collaboration of CBQF under the FCT project UID/ Multi/50016/2019 and NORTE-08-5369-FSE-000007 and CEB under the FCT project UID/BIO/044697/2019 and BioTecNorte operation (NORTE-01-0145-FEDER-000004). 


\section{References}

[1] M.K. de Kreuk, M.C. van Loosdrecht, Formation of aerobic granules with domestic sewage, J. Environ. Eng. 132 (2006) 694-697, https://doi.org/10.1061/(ASCE) 0733-9372(2006)132:6(694).

[2] M.K. de Kreuk, N. Kishida, M.C.M. van Loosdrecht, Aerobic granular sludge - state of the art, Water Sci. Technol. 55 (2007) 75-81, https://doi.org/10.2166/ wst.2007.244.

[3] M.C.M. Van Loosdrecht, M.A. Pot, J.J. Heijnen, Importance of bacterial storage polymers in bioprocesses, Water Sci. Technol. 35 (1997) 41-47, https://doi.org/ 10.1016/S0273-1223(96)00877-3.

[4] S.S. Adav, D.J. Lee, K.Y. Show, J.H. Tay, Aerobic granular sludge: recent advances, Biotechnol. Adv. 26 (2008) 411-423, https://doi.org/10.1016/j. biotechadv.2008.05.002

[5] J.P. Bassin, R. Kleerebezem, M. Dezotti, M.C.M. van Loosdrecht, Measuring biomass specific ammonium, nitrite and phosphate uptake rates in aerobic granular sludge, Chemosphere 89 (2012) 1161-1168, https://doi.org/10.1016/j. chemosphere.2012.07.050.

[6] W. Yin, Y. Wang, L. Liu, J. He, Biofilms: the microbial "protective clothing" in extreme environments, Int. J. Mol. Sci. 20 (2019) 3423, https://doi.org/10.3390/ ijms20143423.

[7] G.P. Sheng, M.L. Zhang, H.Q. Yu, Characterization of adsorption properties of extracellular polymeric substances (EPS) extracted from sludge, Colloids Surf. B Biointerfaces 62 (2008) 83-90, https://doi.org/10.1016/j.colsurfb.2007.09.024.

[8] J. Sipma, M.B. Osuna, M.A.E. Emanuelsson, P.M.L. Castro, Biotreatment of industrial wastewaters under transient-state conditions: process stability with fluctuations of organic load, substrates, toxicants, and environmental parameters, Crit. Rev. Environ. Sci. Technol. 40 (2010) 147-197, https://doi.org/10.1080/ 10643380802039329.

[9] C. Gadipelly, A. Pérez-González, G.D. Yadav, I. Ortiz, R. Ibáñez, V.K. Rathod, K. V. Marathe, Pharmaceutical industry wastewater: review of the technologies for water treatment and reuse, Ind. Eng. Chem. Res. 53 (2014) 11571-11592, https:// doi.org/10.1021/ie501210j.

[10] C.L. Amorim, I.S. Moreira, A.F. Duque, M.C. van Loosdrecht, P.M. Castro, Aerobic granular sludge: treatment of wastewaters containing toxic compounds. Treat. Recover. Nutr. From Ind. Wastewater, 2017, pp. 231-363, https://doi.org/ 10.4018/978-1-5225-1037-6, ch009.

[11] O. Lefebvre, R. Moletta, Treatment of organic pollution in industrial saline wastewater: a literature review, Water Res. 40 (2006) 3671-3682, https://doi.org/ 10.1016/j.watres.2006.08.027.

[12] B.D. Key, R.D. Howell, C.S. Criddle, Fluorinated organics in the biosphere, Environ. Sci. Technol. 31 (1997) 2445-2454, https://doi.org/10.1021/es961007c.

[13] E. Kaczorek, W. Smułek, A. Zdarta, A. Sawczuk, A. Zgoła-Grześkowiak, Influence of saponins on the biodegradation of halogenated phenols, Ecotoxicol. Environ. Saf. 131 (2016) 127-134, https://doi.org/10.1016/j.ecoenv.2016.05.015.

[14] B. Kokabian, B. Bonakdarpour, S. Fazel, The effect of salt on the performance and characteristics of a combined anaerobic-aerobic biological process for the treatment of synthetic wastewaters containing Reactive Black 5, Chem. Eng. J. 221 (2013) 363-372, https://doi.org/10.1016/j.cej.2013.01.101.

[15] A. Assadi, M. Naderi, M.R. Mehrasbi, Anaerobic-aerobic sequencing batch reactor treating azo dye containing wastewater: effect of high nitrate ions and salt, J. Water Reuse Desalin. 8 (2018) 251-261, https://doi.org/10.2166/ wrd.2017.132.

[16] S.F. Corsino, R. Campo, G. Di Bella, M. Torregrossa, G. Viviani, Cultivation of granular sludge with hypersaline oily wastewater, Int. Biodeterior. Biodegrad. 105 (2015) 192-202, https://doi.org/10.1016/j.ibiod.2015.09.009.

[17] R. Campo, G. Di Bella, Petrochemical slop wastewater treatment by means of aerobic granular sludge: effect of granulation process on bio-adsorption and hydrocarbons removal, Chem. Eng. J. 378 (2019) 122083, https://doi.org/ 10.1016/j.cej.2019.122083.

[18] C. Ramos, M.E. Suárez-Ojeda, J. Carrera, Long-term impact of salinity on the performance and microbial population of an aerobic granular reactor treating high-strength aromatic wastewater, Bioresour. Technol. 198 (2015) 844-851, https://doi.org/10.1016/j.biortech.2015.09.084.

[19] C. Ramos, M.E. Suárez-Ojeda, J. Carrera, Biodegradation of a high-strength wastewater containing a mixture of ammonium, aromatic compounds and salts with simultaneous nitritation in an aerobic granular reactor, Process Biochem. 51 (2016) 399-407, https://doi.org/10.1016/j.procbio.2015.12.020.

[20] A.F. Duque, V.S. Bessa, M.F. Carvalho, M.K. de Kreuk, M.C.M. Van Loosdrecht, P. M.L. Castro, 2-Fluorophenol degradation by aerobic granular sludge in a sequencing batch reactor, Water Res. 45 (2011) 6745-6752, https://doi.org/ 10.1016/j.watres.2011.10.033.

[21] C. Ramos, C.L. Amorim, D.P. Mesquita, E.C. Ferreira, J. Carrera, P.M.L. Castro, Simultaneous partial nitrification and 2-fluorophenol biodegradation with aerobic granular biomass: reactor performance and microbial communities, Bioresour. Technol. 238 (2017) 232-240, https://doi.org/10.1016/j.biortech.2017.03.173.

[22] M.K. De Kreuk, J.J. Heijnen, M.C.M. Van Loosdrecht, Simultaneous COD, nitrogen, and phosphate removal by aerobic granular sludge, Biotechnol. Bioeng. 90 (2005) 761-769, https://doi.org/10.1002/bit.20470.

[23] Z. Jemaat, M.E. Suárez-Ojeda, J. Pérez, J. Carrera, Sequentially alternating pollutant scenarios of phenolic compounds in a continuous aerobic granular sludge reactor performing simultaneous partial nitritation and o-cresol biodegradation, Bioresour. Technol. 161 (2014) 354-361, https://doi.org/10.1016/j biortech.2014.03.071.

[24] J.D. Rhoades, A. Kandiah, A.M. Mashali, Saline waters as resources. Use Saline Waters Crop Prod. Guidel. Water, Soil Crop Manag., Food and Agriculture
Organization of the United Nations, Rome, 1992. http://www.fao. org/3/t0667e/t0667e00.htm\#Contents.

[25] The chemistry of processes in the hydrosphere, Environ. Chem., Springer, New York, NY, 2007, pp. 96-136, https://doi.org/10.1007/978-0-387-31435-8_6.

[26] APHA, Standard Methods for the Examination of Water and Wastewater, Am. Public Heal. Assoc., 1998.

[27] C.L. Amorim, I.S. Moreira, A.R. Ribeiro, L.H.M.L.M. Santos, C. Delerue-Matos, M. E. Tiritan, P.M.L. Castro, Treatment of a simulated wastewater amended with a chiral pharmaceuticals mixture by an aerobic granular sludge sequencing batch reactor, Int. Biodeterior. Biodegrad. 115 (2016) 277-285, https://doi.org/ 10.1016/j.ibiod.2016.09.009.

[28] A.S. Oliveira, C.L. Amorim, M.A. Ramos, D.P. Mesquita, P. Inocêncio, E.C. Ferreira, M. Van Loosdrecht, P.M.L. Castro, Variability in the composition of extracellular polymeric substances from a full-scale aerobic granular sludge reactor treating urban wastewater, J. Environ. Chem. Eng. 8 (2020) 104156, https://doi.org/ 10.1016/j.jece.2020.104156.

[29] D.P. Mesquita, O. Dias, A.M.A. Dias, A.L. Amaral, E.C. Ferreira, Correlation between sludge settling ability and image analysis information using partial least squares, Anal. Chim. Acta 642 (2009) 94-101, https://doi.org/10.1016/j. aca.2009.03.023.

[30] C. Leal, A. Val, D.P. Mesquita, A.L. Amaral, P.M.L. Castro, E.C. Ferreira, Sludge volume index and suspended solids estimation of mature aerobic granular sludge by quantitative image analysis and chemometric tools, Sep. Purif. Technol. 234 (2019) 116049, https://doi.org/10.1016/j.seppur.2019.116049.

[31] S. Felz, S. Al-Zuhairy, O.A. Aarstad, M.C.M. van Loosdrecht, Y.M. Lin, Extraction of structural extracellular polymeric substances from aerobic granular sludge, J. Vis. Exp. (2016) e54534 (Accessed 23 May 2017), http://www.ncbi.nlm.nih.gov/pub med/27768085.

[32] H. Schagger, W.A. Cramer, G. Vonjagow, Protein measurement with the folin phenol reagent, Anal. Biochem. 217 (1994) 220-230, https://doi.org/10.1016/ 0304-3894(92)87011-4.

[33] M. Dubois, K.A. Gilles, J.K. Hamilton, P.A. Rebers, F. Smith, Colorimetric method for determination of sugars and related substances, Anal. Chem. 28 (1956) 350-356, https://doi.org/10.1021/ac60111a017.

[34] B. Frølund, T. Griebe, P.H. Nielsen, Enzymatic activity in the activated-sludge floc matrix, Appl. Microbiol. Biotechnol. 43 (1995) 755-761, https://doi.org/10.1007/ BF00164784.

[35] A.F. Duque, V.S. Bessa, M.F. Carvalho, P.M.L. Castro, Bioaugmentation of a rotating biological contactor for degradation of 2-fluorophenol, Bioresour. Technol. 102 (2011) 9300-9303, https://doi.org/10.1016/j.biortech.2011.07.003.

[36] J.P. Bassin, M. Dezotti, G.L. Sant'Anna, Nitrification of industrial and domestic saline wastewaters in moving bed biofilm reactor and sequencing batch reactor, J. Hazard. Mater. 185 (2011) 242-248, https://doi.org/10.1016/j. jhazmat 2010.09.024.

[37] M. Pronk, J.P. Bassin, M.K. De Kreuk, R. Kleerebezem, M.C.M. Van Loosdrecht, Evaluating the main and side effects of high salinity on aerobic granular sludge, Appl. Microbiol. Biotechnol. 98 (2014) 1339-1348, https://doi.org/10.1007/ s00253-013-4912-z.

[38] S.F. Corsino, M. Capodici, M. Torregrossa, G. Viviani, Physical properties and Extracellular Polymeric Substances pattern of aerobic granular sludge treating hypersaline wastewater, Bioresour. Technol. 229 (2017) 152-159, https://doi.org/ 10.1016/j.biortech.2017.01.024.

[39] H.C. Flemming, J. Wingender, The biofilm matrix, Nat. Rev. Microbiol. 8 (2010) 623-633, https://doi.org/10.1038/nrmicro2415.

[40] T.T. More, J.S.S. Yadav, S. Yan, R.D. Tyagi, R.Y. Surampalli, Extracellular polymeric substances of bacteria and their potential environmental applications, J. Environ. Manage. (2014), https://doi.org/10.1016/j.jenvman.2014.05.010.

[41] J.P. Bassin, M. Pronk, G. Muyzer, R. Kleerebezem, M. Dezotti, M.C.M. Van Loosdrecht, Effect of elevated salt concentrations on the aerobic granular sludge process: linking microbial activity with microbial community structure, Appl. Environ. Microbiol. 77 (2011) 7942-7953, https://doi.org/10.1128/AEM.05016 11.

[42] A. Uygur, F. Kargi, Salt inhibition on biological nutrient removal from saline wastewater in a sequencing batch reactor, Enzyme Microb. Technol. 34 (2004) 313-318, https://doi.org/10.1016/j.enzmictec.2003.11.010.

[43] Y. Zhao, H.-D. Park, J.-H. Park, F. Zhang, C. Chen, X. Li, D. Zhao, F. Zhao, Effect of different salinity adaptation on the performance and microbial community in a sequencing batch reactor, Bioresour. Technol. 216 (2016) 808-816, https://doi. org/10.1016/j.biortech.2016.06.032.

[44] D.R. de Graaff, M.C.M. van Loosdrecht, M. Pronk, Biological phosphorus removal in seawater-adapted aerobic granular sludge, Water Res. 172 (2020) 115531, https://doi.org/10.1016/j.watres.2020.115531.

[45] T. Saito, D. Brdjanovic, M.C.M. Van Loosdrecht, Effect of nitrite on phosphate uptake by phosphate accumulating organisms, Water Res. 38 (2004) 3760-3768, https://doi.org/10.1016/j.watres.2004.05.023.

[46] M.K. De Kreuk, M. Pronk, M.C.M. Van Loosdrecht, Formation of aerobic granules and conversion processes in an aerobic granular sludge reactor at moderate and low temperatures, Water Res. 39 (2005) 4476-4484, https://doi.org/10.1016/j. watres.2005.08.031.

[47] M. Figueroa, A. Mosquera-Corral, J.L. Campos, R. Méndez, Treatment of saline wastewater in SBR aerobic granular reactors, Water Sci. Technol. 58 (2008) 479-485, https://doi.org/10.2166/wst.2008.406.

[48] D. Wei, Y. Wang, X. Wang, M. Li, F. Han, L. Ju, G. Zhang, L. Shi, K. Li, B. Wang, B. Du, Q. Wei, Toxicity assessment of 4-chlorophenol to aerobic granular sludge and its interaction with extracellular polymeric substances, J. Hazard. Mater. 289 (2015) 101-107, https://doi.org/10.1016/j.jhazmat.2015.02.047. 
[49] J.W. Lim, S.L. Ng, S.M. Khor, C.E. Seng, Inhibitory effect of 2,4-dichlorophenol on nitrogen removal in a sequencing batch reactor, Korean J. Chem. Eng. 29 (2012) 886-890, https://doi.org/10.1007/s11814-011-0267-2.

[50] B.M. Wilén, R. Liébana, F. Persson, O. Modin, M. Hermansson, The mechanisms of granulation of activated sludge in wastewater treatment, its optimization, and impact on effluent quality, Appl. Microbiol. Biotechnol. 102 (2018) 5005-5020, https://doi.org/10.1007/s00253-018-8990-9.

[51] I.S. Moreira, C.L. Amorim, A.R. Ribeiro, R.B.R. Mesquita, A.O.S.S. Rangel, M.C M. Van Loosdrecht, M.E. Tiritan, P.M.L. Castro, Removal of fluoxetine and its effects in the performance of an aerobic granular sludge sequential batch reactor, J. Hazard. Mater. 287 (2015) 93-101, https://doi.org/10.1016/j. jhazmat.2015.01.020.

[52] C.L. Amorim, A.S. Maia, R.B.R. Mesquita, A.O.S.S. Rangel, M.C.M. Van Loosdrecht, M.E. Tiritan, P.M.L. Castro, Performance of aerobic granular sludge in a sequencing batch bioreactor exposed to ofloxacin, norfloxacin and ciprofloxacin, Water Res. 50 (2014) 101-113, https://doi.org/10.1016/j.watres.2013.10.043.

[53] J.P. Bassin, D.C. Tavares, R.C. Borges, M. Dezotti, Development of aerobic granular sludge under tropical climate conditions: the key role of inoculum adaptation under reduced sludge washout for stable granulation, J. Environ. Manage. 230 (2019) 168-182, https://doi.org/10.1016/j.jenvman.2018.09.072.

[54] M.K. de Kreuk, M.C.M. van Loosdrecht, Selection of slow growing organisms as a means for improving aerobic granular sludge stability, Water Sci. Technol. 49 (2004) 9-17, https://doi.org/10.2166/wst.2004.0792.

[55] B. Nguyen Quoc, S. Wei, M. Armenta, R. Bucher, P. Sukapanpotharam, D.A. Stahl, H.D. Stensel, M.K.H. Winkler, Aerobic granular sludge: impact of size distribution on nitrification capacity, Water Res. 188 (2021) 116445, https://doi.org/10.1016/ j.watres.2020.116445.
[56] D.P. Mesquita, R.R. Ribeiro, M.A.Z. Coelho, Image analysis application for the study of activated sludge floc size during the treatment of synthetic and real fishery wastewaters, Environ. Sci. Pollut. Res. 18 (2011) 1390-1397, https://doi.org/ 10.1007/s11356-011-0496-2.

[57] G.P. Sheng, H.Q. Yu, Z.B. Yue, Production of extracellular polymeric substances from Rhodopseudomonas acidophila in the presence of toxic substances, Appl. Microbiol. Biotechnol. 69 (2005) 216-222, https://doi.org/10.1007/s00253-0051990-6.

[58] K. Li, D. Wei, T. Yan, B. Du, Q. Wei, Responses of soluble microbial products and extracellular polymeric substances to the presence of toxic 2,6-dichlorophenol in aerobic granular sludge system, J. Environ. Manage. 183 (2016) 594-600, https:// doi.org/10.1016/j.jenvman.2016.09.014.

[59] S.S. Adav, D.J. Lee, J.H. Tay, Extracellular polymeric substances and structural stability of aerobic granule, Water Res. 42 (2008) 1644-1650, https://doi.org/ 10.1016/j.watres.2007.10.013.

[60] H. Chen, S. Zhou, T. Li, Impact of extracellular polymeric substances on the settlement ability of aerobic granular sludge, Environ. Technol. 31 (2010) 1601-1612, https://doi.org/10.1080/09593330.2010.482146.

[61] H. Liu, H.H.P. Fang, Extraction of extracellular polymeric substances (EPS) of sludges, J. Biotechnol. 95 (2002) 249-256, https://doi.org/10.1016/S0168-1656 (02)00025-1.

[62] H.-C. Flemming, J. Wingender, U. Szewzyk, P. Steinberg, S.A. Rice, S. Kjelleberg, Biofilms: an emergent form of bacterial life, Nat. Rev. Microbiol. 14 (2016) 563-575, https://doi.org/10.1038/nrmicro.2016.94.

[63] S.F. Corsino, M. Capodici, M. Torregrossa, G. Viviani, Fate of aerobic granular sludge in the long-term: the role of EPSs on the clogging of granular sludge porosity, J. Environ. Manage. 183 (2016) 541-550, https://doi.org/10.1016/j. jenvman.2016.09.004 